\title{
Kriittistä psykologisen sopimuksen teorian ja tutkimuksen kehittämistä
}

Griep, Yannick \& Cooper, Cary (toim.) Handbook of Research on the Psychological Contract at Work, Cheltenham, UK: Edward Elgar Publishing, 2019, 430 sivua.

Psykologisia sopimuksia työelämässä on tutkittu jo 1960-luvulta lähtien ja aihe on edelleen ajankohtainen. Työelämä jatkaa muutostaan ja samalla myös psykologisten sopimusten sisällöt muuttuvat ja teorian kehittäminen jatkuu. Varsinaista psykologisen sopimuksen tutkimuksen käsikirjaa ei ole kuitenkaan aiemmin ilmestynyt. Psykologisen sopimuksen tutkimuksessa on olemassa muutamia keskeisiä teoksia, jotka ovat vakionimekkeitä alan tutkimusten lähdeluetteloissa. Näistä ensimmäisenä esimerkkinä teoriaa uudelleenmuotoilleen Denise Rousseaun (1995) opastyyppinen teos Psychological Contracts in Organizations, joka kertoo hänen tulkintansa eri sopimustyypeistä ja niiden sisällöistä. Toinen luottoteos on Neil Conwayn ja Rob B. Brinerin (2005) Understanding Psychological Contracts at Work, joka kuvaa teorian historian ja sopimusmallien muotoutumisen ja sisällöt sekä tarjoaa nipun mittareita kvantitatiivisen tutkimuksen käyttöön.

Nyt on kuitenkin käsillä aiheen varsinainen käsikirja, joka summaa 47 kirjoittajan osaamisen. Toivoin, että tämä olisi se puuttuva ja kaiken kattava käsikirja, joka toimii ensiapuna tutkimuksen teon eri vaiheissa sekä opiskelijoille että tutkijoille. Kuitenkin jo ensitarkastelussa tulee vaikutelma, että käsikirjanimestään huolimatta kyseessä ei ole sellainen käsikirja, jota voisi välttämättä suositella lukijalle, joka on vasta törmännyt termiin psykologinen sopimus. Teos ei siis tarjoa käteviä rautalankamalleja tai helppoa tapaa selvittää psykologisen sopimuksen perusteita. Sen sijaan teos summaa jo tehtyä tutkimusta usein melko kriittisestä näkökulmasta. Teoksen lähtökohtana onkin esittää, mitä ongelmia jo tehdyssä tutkimuksessa on, mitä uusia avauksia on tehty ja mitä uutta vielä tarvitaan. Yhdessäkään luvussa ei esimerkiksi erityisesti käsitellä usein tutkimuksen keskiössä olevia sopimustyyppejä eli jakoa relationaaliseen, transaktionaaliseen, transitionaaliseen ja tasapainotettuun sopimukseen. Teoksessa ei myöskään käsitellä sopimustyyppien toimivuutta tutkimuksessa, joten tämän tyyppisiä perustietoja kannattaa hakea muista lähteistä.

Heti kirjan toimittajien kirjoittamassa johdannossa tehdäänkin selväksi, että maailmassa on jo riittävästi hyviä kirjoja, jotka käsittelevät psykologisen sopimuksen teoriaa ja empiirisiä tutkimuksia, kuten edellä mainitut Rousseaun sekä Conwayn ja Brinerin teokset. Tämän käsikirjan tarkoitus ei siis toimittajien mukaan ole toistaa, päivittää tai arvioida näiden kirjojen sisältöä. Sen sijaan sen tarkoitus on arvioida kriittisesti aiempaa tutkimusta, tehdä uusia teoreettisia avauksia, huomioida ajallinen ulottuvuus psykologisen sopimuksen toiminnassa sekä tarjota uusia analyyttisiä ja metodologisia työkaluja. Kirja on järjestetty näiden tavoitteiden mukaan neljään osaan. Selkeä tavoitteiden mukainen järjestely ja lukujen napakka esittely johdannossa auttavat kirjan kokonaisuuden hahmottamisessa ja tekevät siitä nimensä mukaisesti käsikirjan.

Perusasioiden kertaamisen sijaan teos lähtee liikkeelle sen pohtimisesta, onko teoria 
ja sen tutkimus nyt pelkästään vanhempaa vai onko se myös viisaampaa. Neil Conway ja Claire Peckan antavat luvussaan kipakan lähtöpotkun koko teokselle väitteellään, että vaikka aihetta tutkitaan paljon, suurin osa tutkimuksesta lähestyy teoriaa hyvin yhteneväiseen tyyliin. Tähän tyyliin kuuluvat Denise Rousseaun konseptualisointiin nojaaminen ja perustason kvantitatiivisten menetelmien soveltaminen poikkileikkausaineistoihin. Kirjoittajat antavat vielä lisäpotkun summaamalla tutkimuksen olevan laajaa, mutta keskittyvän kapeakatseisesti psykologiseen sopimukseen sisältyviin lupauksiin. Näistä kriittisistä alkuasetelmista ponnistava kirja onnistuu summaamaan hyvin psykologisen sopimuksen tutkimuksen kentän tapahtumat ja uusimmat avaukset.

Ensimmäinen osa tarjoaa eniten tarttumapintaa lukijalle, joka ei ole vielä uponnut kovin syvälle psykologisen sopimuksen teoriaan, vaan kaipaa kriittistä näkökulmaa sen tutkimuksen menneisyyteen ja nykykeskusteluihin. Ensimmäisen osion helmi on René Schalkin ja Melanie De Ruiterin luku, joka käsittelee psykologisen sopimuksen keskinäisyyttä ja vastavuoroisuutta. Näitä käsitteitä ei ole niiden runsaasta käytöstä huolimatta kirjoittajien mukaan määritelty tutkimuksessa yksiselitteisesti, joten kirjallisuuskatsauksen tulosten perusteella he antavat ehdotuksensa määritelmiksi. Sopimuksen keskinäisyys määriteltäisiin siten heidän mukaansa "yhteisymmärryksen tasoksi psykologisen sopimuksen ehdoista" ja vastavuoroisuus "vaihdon tasapainoksi".

Toisen eli uusia teoreettisia avauksia tarjoavan osan ehdottomasti parasta antia on Maria Tomproun ja Sarah Bankinsin luku. Se käsittelee psykologisen sopimuksen rikkoutumista ja huomioi sekä kutsumuksen merkityksen että haavoittuvassa asemassa olevat työntekijät. Luvussa kuvataan tutkimuksissa melko vähälle huomiolle jääneitä psykologisen sopimuksen rikkoutumisen jälkeisiä tapahtumakulkuja, jotka johtavat joko sopimuksen palautumiseen ennalleen tai sen muuttumiseen. Kirjoittajien mukaan työtä kohtaan koet- tu kutsumus on työntekijälle usein merkityksellisempi kuin psykologinen sopimus. Vaikka psykologinen sopimus tulisikin rikotuksi, eli työnantaja ei täytä työntekijän odotuksia, voi kutsumus silti pitää työntekijän kiinni organisaatiossa. Kirjoittajat huomauttavat, että suurin osa psykologisen sopimuksen tutkimuksesta kohdistuu asiantuntijaorganisaatioihin ja sivuuttaa sellaiset tehtävät, joissa on vähemmän vaikutus- ja toimintamahdollisuuksia. Haavoittuvissa asemissa olevien työntekijöiden psykologisen sopimuksen rikkomiset voivat olla turhautumisen ja pettymyksen lisäksi myös suoranaista hyväksikäyttöä ja perusoikeuksien, kuten työturvallisuuden, laiminlyöntiä. Tällaisissa tilanteissa edes kutsumus ei suojaa sopimuksen rikkomiselta, ja kirjoittajat ehdottavat selviytymismekanismeiksi esimerkiksi kollektiivista selviytymistä työyhteisön tukiessa jäseniään.

Kolmannessa osassa on vain kolme artikkelia, joista jokainen kehittää dynaamisuuden ja ajallisen ulottuvuuden huomioimista psykologisen sopimuksen toiminnassa. Hermien Wiechers, Jacqueline A-M. Coyle-Shapiro, Xander Lub ja Steven ten Have tiivistävät ajallisuuden ohittamisen ongelman hyvin. Heidän mukaansa psykologisen sopimuksen rikkoutuminen on teorian tärkeimpiä osia, koska sen kautta voidaan ymmärtää sopimuksen vaikutuksia työntekijöiden tunteisiin, asenteisiin ja käytökseen. Tutkimuksissa sopimuksen rikkoutumisen esitetään kuitenkin usein johtuvan vain yhdestä tapahtumasta tai väärinkäytöksestä, mutta samaan aikaan ristiriitaisesti hyväksytään ajatus sopimuksen jatkuvasta kehittymisestä. Kirjoittajien mukaan rikkoutuminen onkin monimutkaisemman ja pidemmän kehityskulun tulosta, ja tätä dynamiikkaa ja ajan merkitystä siinä tulisi tutkia enemmän.

Viimeinen eli neljäs osa tarjoaa uusia metodologisia avauksia, kuten mallinnusta, kokeellisia asetelmia ja narratiivista lähestymistapaa psykologiseen sopimukseen. Neljännen osan päättää lukuisten tutkijoiden yhteinen osio, jossa hahmotellaan psykologisen sopimuksen tutkimuksen tulevaisuutta. Luvun kirjoit- 
tajiin lukeutuu myös psykologisen sopimuksen tutkimuksen keskeisin kehittäjä, Denise Rousseau, jolta ei jostain syystä ikävä kyllä ole kirjassa muuta kontribuutiota. Viimeisessä luvussa kirjoittajat tiivistävät, että tulevaisuudessa tarvitaan tutkimusta vastaamaan erityisesti kysymyksiin ajan, sosiaalisen kontekstin ja työn luonteen muutoksen merkityksestä psykologisessa sopimuksessa. Vielä tarvitaan siis tutkimusta esimerkiksi siitä, miten työntekijöiden odotukset muuttuvat ajan myötä, miten sosiaalinen konteksti vaikuttaa sopimusrikkomusten syntyyn ja seurauksiin sekä miten psykologisen sopimuksen teoria pysyy perässä, kun se, missä, miten, milloin ja miksi työtä tehdään, muuttuu jatkuvasti.
Kokonaisuutena kirja summaa hyvin tähänastisen psykologisen sopimuksen tutkimuksen saavutukset ja ongelmat. Se tarjoaa myös tukun ratkaisuja näihin ongelmiin sekä runsaasti uusia avauksia ja kysymyksiä tulevaisuuden tutkimuksen käyttöön.

\section{Kirjoittaja}

Tiina Saari, YTT, tutkijatohtori, Tampereen yliopisto, sähköposti: tiina.saari@tuni.fi 